\title{
Self-employment and poverty in developing
} countries

\section{The right policies can help the self-employed to boost their earnings above the poverty level and earn more for the work they do}

Keywords: self-employment, poverty, labor earnings

\section{ELEVATOR PITCH}

A key way for the world's poor-nearly half of humanity-to escape poverty is to earn more for their labor. Most of the world's poor people are self-employed, but because there are few opportunities in most developing countries for them to earn enough to escape poverty, they are working hard but working poor. Two key policy planks in the fight against poverty should be: raising the returns to self-employment and creating more opportunities to move from selfemployment into higher paying wage employment.

\section{KEY FINDINGS}

\section{Pros}

(- Most workers in low- and middle-income countries are self-employed, but earnings are typically higher and social protection programs are more widespread in wage employment.

๑ Most workers are self-employed because they have no choice.

$\rightarrow$ One goal for public policy would be to raise the returns to the labor of the self-employed.

๑ Another goal would be to move the self-employed into wage employment.

๑ Improving the earning opportunities, creating off-farm employment, training people for wage employment, and making microcredit affordable are among the most promising policy interventions.
Self-employment in developing countries (\%)

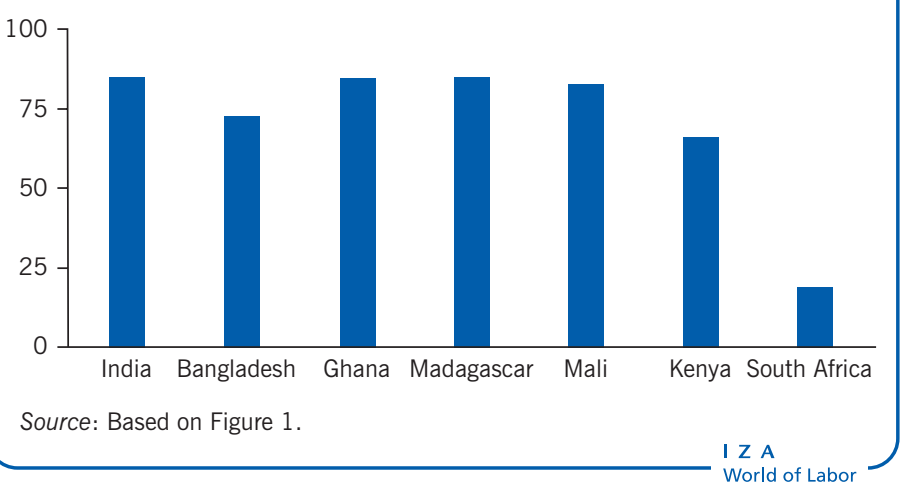

\section{Cons}

- Absolute poverty is not primarily a problem of unemployment, but a problem of low labor market earnings among the employed.

- Not enough is known about how many of the selfemployed previously worked in wage employment, or why they left.

- Self-employment is not the same as entrepreneurship, nor is self-employment necessarily informal.

- Although some regulation is necessary and appropriate, the self-employed are often hindered excessively, which unfairly limits their earning power and may deprive them of their means of earning a livelihood.

\section{AUTHOR'S MAIN MESSAGE}

Governments should support self-employment as a means of creating livelihood opportunities for the poor and expand opportunities for better-paying wage employment. Too often, public policies hinder the self-employed. With the right policies in place, the self-employed can boost their earnings above the poverty level. Four interventions have proved effective in a range of settings: focusing economic growth on improving earning opportunities for the poor, creating off-farm jobs, training for wage employment, and making microcredit affordable. 


\section{MOTIVATION}

Three billion people in the world live on less than $\$ 2.50$ a day [1]. Referred to as the "absolutely poor," they are overwhelmingly concentrated in developing countries. Although they work, they are poor because there are not adequate opportunities for them to earn enough to escape poverty. They are working hard but working poor [2].

Poor people typically respond to the lack of adequate employment opportunities by creating their own employment. Most do this out of desperation: the only alternative to working and earning very little is to be unemployed and earning nothing.

In low- and middle-income countries (developing countries), the number of people wanting employment and capable of working in wage employment far exceeds the number of jobs. Some poor people prefer self-employment to wage employment, but for most, selfemployment is worse than wage employment. Yet in the absence of unemployment insurance and other social protection programs, it is better than nothing.

\section{Who are the poor?}

In 2011, 1.3 billion people lived on less than $\$ 1.25$ a day in purchasing power parity-adjusted dollars; these people are often referred to as the "extremely poor." Another 1.7 billion people lived on $\$ 1.25-\$ 2.50$ a day. Together, these poor people are identified as the "absolute" or the "global" poor: people with the same purchasing power over commodities, no matter where they live, based on minimum nutritional requirements for good health and normal activities. In addition, poverty is measured in two other ways in individual countries. Some use country-specific poverty lines (for example, the country-specific poverty line for the US is much higher than the one for India, reflecting the US' higher national income). While other countries, particularly in Europe, typically measure relative poverty, with the relative poverty line being set as a percentage of average income..

\section{DISCUSSION OF PROS AND CONS}

\section{Poverty and undersupported labor markets are linked}

The first Millennium Development Goal (MDG), for good reason, is to eradicate extreme poverty and hunger. Several other MDGs have been met on a global scale, including the target of halving the proportion of people without access to improved sources of water and reaching parity in primary education between girls and boys. The United Nations reports that extreme poverty is falling in every region of the world and that the poverty reduction target of cutting global poverty in half by 2015 has been met [3]. Despite this progress, worldwide poverty remains enormous. Accordingly, the international community is calling for a new target for MDG 1: eliminating extreme poverty by 2030.

Because labor is the main asset of the poor, unemployment is often thought to be the main reason for poverty. This is wrong. In a given week, some 200 million people are unemployed and earning nothing [4]. This is a large number, but it pales beside the 900 million people who are employed but earn so little, in cash or in kind, that they and their families cannot achieve a standard of living of even $\$ 2$ per person a day [4]. What differentiates people who are poor from those who are not, then, is not whether they are employed, but how much they and other household members earn from the work they do. 


\section{Millennium Development Goals (MDGs)}

In 2000, a meeting took place at the United Nations (UN) between leaders of virtually all countries. They agreed on ambitious development goals to eradicate poverty and also to improve human well-being by reducing illiteracy, hunger, discrimination, unsafe drinking water, and degraded environments.

The eight Millennium Development Goals (MDGs) are:

1 Eradicate extreme poverty and hunger.

2 Achieve universal primary education.

3 Promote gender equality and empower women.

4 Reduce child mortality.

5 Improve maternal health.

6 Combat HIV/AIDS, malaria, and other diseases.

7 Ensure environmental sustainability.

8 Develop a global partnership for development.

Each goal is set with measurable targets, the majority of which are benchmarked for the period 1990-2015 and promise measurable improvements by the end of 2015. Progress is measured through a set of 21 time-bound targets and 60 indicators.

Member States of the UN are now defining Sustainable Development Goals (SDGs), which will form the foundation of the post-2015 development agenda, continuing the work on the MDGs.

Source: United Nations. The Millennium Development Goals Report 2014. Online at: http://www. un.org/millenniumgoals/2014\%20MDG\%20report/MDG\%202014\%20English\%20web.pdf and http://www.un.org/millenniumgoals/

\section{Most workers in developing countries are self-employed}

In developing economies, as noted, many poor people-often a majority-are self-employed. They work in individual or household enterprises in both urban and rural areas and inside and outside agriculture. Self-employed individuals who do not employ others are sometimes called "own-account workers."

More than half of workers in low-income countries (53\%) and more than a third in lowermiddle-income countries (36\%) are self-employed, mainly in agriculture in both cases. Rates of self-employment or casual employment are particularly high in South Asia and SubSaharan Africa; South Africa is an outlier, with only $19 \%$ of the employed population selfemployed (Figure 1; illustration p. 1). Also, in Sub-Saharan Africa, most new nonfarm jobs are generated by people starting household enterprises. Fully half of the extremely poor in urban areas operate a nonagricultural business, according to an 18-country study [5]. 
Figure 1. Self-employment is high in most developing regions and countries — Some examples

\begin{tabular}{ll}
\hline Region and country & Percentage self-employed \\
\hline South Asia & \\
India & 85 \\
Bangladesh & 73 \\
& \\
Sub-Saharan Africa & 85 \\
Ghana & 85 \\
Madagascar & 83 \\
Mali & 66 \\
Kenya & 19 \\
South Africa & \\
\hline
\end{tabular}

Source: Banerjee, A. V., and E. Duflo. Poor Economics. New York: PublicAffairs Press, 2011, p. 210 [5].

\section{Self-employment is not the same as entrepreneurship or informal employment}

Self-employment is sometimes equated with entrepreneurship, but this can be misleading. To many people, "entrepreneurship" conjures the image of a risk-taker setting up a business with the intent of making it grow and prosper. In developing countries, however, the goal of much self-employment is far more modest: to earn money for a time-preferably, a short time-before transitioning to a more remunerative activity.

An example is saving money to buy a package of 20 cigarettes and then selling them individually at a higher unit price and surviving on the profits. Workers (mostly young men) engaged in such survival self-employment can hardly be called "entrepreneurs" in the everyday sense of the term. They engage in such activities reluctantly and only until they can find something better. The majority of self-employment enterprises lack the potential to grow, as studies in Sri Lanka and West Africa demonstrate.

Self-employment is also sometimes equated with working informally. But equating the two is unhelpful. "Working informally" and the associated terms "informal economy" and "informal sector" are not defined consistently, so "informality" means different things to different people. And even when the conceptualization is clear, as when informal employment refers to work outside the protection and regulation of the state, it is difficult to take this concept to data.

While many people who engage in unprotected and unregulated work are paid workers, not self-employed, there are only vague estimates of how many there are. Even less is known about how many self-employed people are engaged in informal activity according to the unprotected/unregulated definition and how many are not. The evidence points to most own-account enterprises and other very small firms being unregistered despite government efforts to get them to register [6].

\section{Does self-employment reflect choice-or lack of choice?}

The literature distinguishes two quite different reasons for self-employment. Clearly, a large number of people are self-employed because they do not have the possibility of being wage 
employees, a condition they would prefer. In this sense, they are self-employed because they have no choice. They are too poor to remain unemployed and earn nothing. A much smaller group of people are self-employed because they were previously wage employees and could have continued in wage employment but left their jobs willingly to create their own enterprises.

Controversy remains over the relative importance of choice and no-choice routes to selfemployment, and more research is needed to investigate this issue in specific countries. But regardless of whether the percentage of people who are working in self-employment because they have no choice is $80 \%$ or $60 \%$, the number is enormous.

The self-employed are largely poor. The international network Women in Informal Employment: Globalizing and Organizing (WIEGO) finds that the self-employed are concentrated in high-poverty-risk, low-average-earnings categories [7]. In the words of one study of the working poor: "Perhaps the many businesses of the poor are less a testimony to their entrepreneurial spirit than a symptom of the dramatic failure of the economies in which they live to provide them with something better" [5].

\section{Women in Informal Employment: Globalizing and Organizing (WIEGO)}

Women in Informal Employment: Globalizing and Organizing (WIEGO) is a global actionresearch-policy network that aims to enhance the status of poor people (especially women) working in informal employment. Its key mission is to empower these workers economically, so that they have equal opportunities and rights.

The network comprises: membership-based organizations of informal workers; researchers looking at the informal economy; and professionals from development agencies who work on issues related to the informal economy.

WIEGO seeks to improve conditions for the working poor in the informal economy by increasing their voice, visibility, and validity-addressing low earnings, high risks, and adverse working environments. They do this by: researching the experiences of those informally employed; educating policy decision-makers and the public about ways to improve circumstances; and helping membership-based organizations of the working poor.

As of May 2014, WIEGO had 177 members from 41 countries.

Source: http://wiego.org/

\section{How policies harm the working poor: Hindrances, restrictions, and regulations}

Street vendors are ubiquitous through the developing world. They sell handicrafts, ice cream, lottery tickets, and just about everything else. But South Africa is different [8]. In cities like Johannesburg, Cape Town, and Durban, street vending is entirely absent or confined to a very restricted area. The reason is local government policies: for example, Durban had issued just 872 trading permits as of 2005, far fewer than the number of people who want to be street traders. The government arrests, fines, or jails unlicensed traders and confiscates their inventory. This all-too-real threat deprives countless people of a livelihood.

Some regulations are needed to protect against abuses. Products that are illegal or dangerous need to be regulated. And some sales practices are threatening to customers, who need to be protected. But some regulations and restrictions needlessly hinder the self-employed poor and prevent them from earning even a meager living. 


\section{Two groups of beneficial policy measures to support the self-employed}

Policy interventions to boost the labor market earnings of the self-employed can be put into two broad groups: those that raise the returns to the self-employed in their current activities and sectors, and those that help the self-employed transition into new, better-paying wage activities.

\section{Labor markets}

Labor markets are the mechanisms that enable labor services to be bought and sold. They include wage employment, where employees sell labor services to an employer, as well as self-employment, where workers sell labor services to themselves. Labor markets include both agricultural and nonagricultural activities.

Policies that can raise the returns to the self-employed in their current activities and sectors include:

- $\quad$ adopting a positive policy stance toward the self-employed that avoids hampering them;

- designing productive inputs (such as irrigation equipment) that can raise the productivity of the self-employed;

- providing poor farmers with more to work with, such as more land, equipment, extension and outreach services, and fertilizer and other inputs;

- facilitating off-farm wage employment and self-employment in rural nonfarm enterprises;

- making capital available to the poor at affordable rates;

- building skills and business know-how;

- $\quad$ stimulating microfinance and microfranchising.

Other policies can expand opportunities for wage employment so that the self-employed poor can move into more remunerative employment. These include general measures affecting labor markets:

- Stimulating job-enhancing economic growth.

- Working toward a more open, but not predatory, international trade environment.

- Encouraging more foreign aid.

- Harnessing the energies of private companies.

Policies can also include labor market measures aimed specifically at generating more wage employment:

- Avoiding prematurely high labor costs.

- Removing excessive barriers to employment. 
- Increasing workers' skills and productive abilities in areas where job vacancies go unfilled because people lack the skills needed to fill them.

- Establishing workfare and other programs aimed at creating jobs for the poor.

The highest priority interventions vary from country to country, and from place to place and group to group within a country. Countries have different objectives and different tradeoffs and constraints on both the policy and the budget sides. The constraints bind differently, the most obstructive constraints differ by circumstances, and the most cost-effective way of intervening to relax the constraints also varies. The World Bank's 2013 World Development Report entitled Jobs offers an eight-way typology for prioritizing policy interventions for different categories of countries [9].

In all countries, however, policies are needed that provide opportunities for poor, selfemployed workers to earn more at their current activity or move into more remunerative activities. To be avoided are policies, evident in many countries, that make life more difficult for the self-employed and deprive them of the opportunity to earn a living.

As always, no single policy or group of policies will work everywhere. But there are some particularly promising interventions that have succeeded in multiple contexts, and some of them are highlighted in what follows.

\section{Some especially promising policy interventions to assist the self-employed poor}

Four interventions appear to be particularly effective and could guide future efforts to improve employment opportunities for the poor [2]:

- focusing economic growth on improving the earning opportunities of the poor;

- creating off-farm employment opportunities;

- training people for wage employment; and

- $\quad$ making microcredit affordable.

These policy priorities are not the only potentially powerful policy interventions. Entrepreneurship policies might also be worth pursuing [10]. But these four policy priorities hold particular promise and have demonstrated their effectiveness in a range of settings.

\section{Focusing economic growth on improving the earning opportunities of the poor: The East Asian experience}

Across East Asia, the growth paths pursued by Japan, then the Asian tigers (Hong Kong, Taiwan, Singapore, and South Korea), then the Asian cubs (Indonesia, Malaysia, Philippines, and Thailand), and then China and Vietnam have improved conditions for workers by focusing production not only on the domestic market but also on exports to the rest of the world. The self-employed benefited from this economic growth by remaining self-employed and participating in the expanding supply chain, by being hired into wage jobs, and by taking advantage of government programs previously unavailable or unaffordable to them. The growth in labor earnings spread beyond the target manufacturing sectors in these countries to wage employees and the self-employed in agriculture and services. The benefits of the tighter labor market brought about by economic growth have been widespread. 


\section{Creating off-farm employment opportunities in rural areas: India's National Rural Employment Guarantee Act}

India's National Rural Employment Guarantee Act (MGNREGA) is the most ambitious workfare program ever attempted. In all 625 districts in India, rural households are guaranteed 100 days of employment a year. More than just an opportunity to apply for work, this program entitles all rural households to take advantage of the employment guarantee. Program participants include the self-employed, workers in household enterprises, and day laborers. Despite some "operational deficiencies" on the ground (a polite way of saying "corruption"), the program is credited with substantially raising the labor earnings of rural workers.

\section{Training people for wage employment: Mexico's Becate program}

One way to help the self-employed is to equip them with the skills to fill existing job vacancies. The government of Mexico created the job-training program Becate (formerly Sicat and before that Probecat) to enable employers to offer training in the skills they need. The government does not prescribe what these skills should be-employers do-so training is offered in specific areas, such as air conditioning repair and lathe operation. Among the beneficiaries are previously self-employed people who are able to move from low-paying selfemployment into better-paying wage employment.

\section{Making microcredit affordable: Andhra Pradesh's Self-Help Group model}

Across developing countries, the self-employed would willingly invest in many potentially profitable activities if they could secure affordable credit. But in most countries, the selfemployed face usurious interest rates: $10 \%$ a month in much of the developing world, $40 \%$ a month in the Philippines, and $4.7 \%$ a day in Chennai, India. In the Indian state of Andhra Pradesh, with a population of 80 million people, the government has moved to remedy this situation by establishing a program for banks to lend to groups of women, rather than to individual women, and charge $12 \%$ interest a year. Borrowers are offered a promptrepayment incentive by the state government, which gives borrowers a 9 percentage point subsidy if they repay their loans on time, lowering their effective interest rate to $3 \%$ a year.

\section{LIMITATIONS AND GAPS}

The largest gap in understanding self-employment in developing countries is knowing why so many people are self-employed. How many self-employed people came to self-employment after wage employment? Could their wage employment have continued, or were they in casual employment that ended? Are people choosing self-employment because of such nonwage benefits as being one's own boss and enjoying greater flexibility between work and family responsibilities? What are the roles of family, personal preference, and health status? How do workers' net earnings in self-employment compare with what they might have earned in wage employment? How do the answers to these questions differ by gender?

Another major gap is the lack of social (rather than personal) cost-benefit analysis of possible policy interventions. How do the direct social benefits of any given intervention compare with the direct social costs? Because there are always policy tradeoffs (the opportunity 
cost of one policy precluding another), it is important to know which policy intervention produces the highest social benefits relative to its costs. In which circumstances have various policy interventions proved socially beneficial and in which have they not?

Finally, more research is needed to establish how many people are self-employed by choice and how many because they have no choice. The numbers in the second category are clearly large, but greater precision is needed, especially on a country by country basis, to end the controversy over exact numbers.

\section{SUMMARY AND POLICY ADVICE}

Self-employment is the predominant mode of economic activity among the world's poor, but because there are few opportunities in most developing countries for the self-employed to earn enough to escape poverty, they are working hard but working poor. Self-employment should be recognized as an important means of providing the poor with a decent livelihood and deserving of support so that the self-employed can escape from poverty.

Two key policy planks in the fight against global poverty should be raising the returns to self-employment and creating more opportunities for poor people to transition from self-employment into higher paying wage employment. Four interventions appear to be particularly effective and could guide efforts to improve employment opportunities for the poor:

- focusing economic growth on improving the earning opportunities of the poor;

- creating off-farm employment opportunities;

- $\quad$ training people for wage employment; and

- $\quad$ making microcredit affordable.

These four measures have demonstrated their effectiveness in a range of settings. Entrepreneurship policies might also be worth pursuing. And, above all, governments should avoid over-regulation that hinders rather than supports the self-employed.

\section{Acknowledgments}

The author thanks an anonymous referee and the IZA World of Labor editors for many helpful suggestions on earlier drafts. This article is based on Fields, G.S. Self-Employment in the Developing World. Background Research Paper, submitted to the UN High Level Panel on the Post-2015 Development Agenda, May 2013 (online at: http://www.post2015hlp.org/ the-report).

\section{Competing interests}

The IZA World of Labor project is committed to the IZA Guiding Principles of Research Integrity. The author declares to have observed these principles.

(c) Gary S. Fields 


\section{REFERENCES}

\section{Further reading}

Baumol, W. J., and M. A. Schilling. "Entrepreneurship." In: Durlauf, S. N. and L. E. Blume, (eds). The New Palgrave Dictionary of Economics. 2nd edition. Palgrave Macmillan, 2008.

Charmes, J. "The informal economy worldwide: Trends and characteristics." Margin: The Journal of Applied Economic Research 6:2 (2012): 103-132.

Gindling, T. H., and D. Newhouse. "Self-employment in the developing world." World Development 56 (2014): 313-331.

The High-Level Panel of Eminent Persons on the Post-2015 Development Agenda. A New Global Partnership: Eradicate Poverty and Transform Economies through Sustainable Development. New York: United Nations, 2013.

Kim, J. Y., World Can End Extreme Poverty and Increase Shared Prosperity. Washington, DC: World Bank, 2013. Online at: http://www.worldbank.org/en/news/video/2013/04/02/jim-kim-world-can-endextreme-poverty

\section{Key references}

[1] Chen, S., and M. Ravallion. An Update to the World Bank's Estimates of Consumption Poverty in the Developing World. Washington, DC: World Bank, 2012.

[2] Fields, G. S. Working Hard, Working Poor. New York: Oxford University Press, 2012.

[3] United Nations. The Millennium Development Goals Report 2012. New York: UN, 2012.

[4] International Labour Organization. Global Employment Trends. Geneva: International Labour Office, 2013.

[5] Banerjee, A. V., and E. Duflo. Poor Economics. New York: Public Affairs Press, 2011.

[6] McKenzie, D., and M. Bruhn. Entry Regulation and Formalization of Microenterprises in Developing Countries. World Bank Policy Research Working Paper 6507. Washington, DC, 2013.

[7] Chen, M. A. The Informal Economy: Definitions, Theories and Policies. Cambridge, MA: Women in Informal Employment: Globalizing and Organizing, 2012.

[8] Skinner, C. "The struggle for the streets: Processes of exclusion and inclusion of street vendors in Durban, South Africa." Development Southern Africa 25:2 (2008).

[9] World Bank. World Development Report 2013: Jobs. Washington, DC: World Bank, 2013.

[10] Cho, Y., and M. Honorati. Entrepreneurship Programs in Developing Countries: A Meta Regression Analysis. World Bank Policy Research Working Paper 6402. Washington, DC, 2013.

The full reference list for this article is available from the IZA World of Labor website (http://wol.iza.org/articles/self-employment-and-poverty-in-developing-countries). 